\title{
The Expatriates Pull Factors in the Gulf Cooperation Council Countries
}

\author{
Aaron Paul M. Pineda, Maria Matriano, Gbenga Ekundayu \\ Middle East College, Knowledge Oasis Muscat, MUSCAT, Sultanate of Oman \\ Email address: \\ aaronpaulpineda.app@gmail.com (A. P. M. Pineda), teresamatriano2004@gmail.com (M. Matriano), \\ cosbi22002@yahoo.com (G. Ekundayu)
}

\section{To cite this article:}

Aaron Paul M. Pineda, Maria Matriano, Gbenga Ekundayu. The Expatriates Pull Factors in the Gulf Cooperation Council Countries. Science Journal of Business and Management. Vol. 4, No. 6, 2016, pp. 223-228. doi: 10.11648/j.sjbm.20160406.17

Received: October 15, 2016; Accepted: December 12, 2016; Published: January 6, 2017

\begin{abstract}
Migration in developing nations is due to rapid growth in urban areas. There are times when people don't get proper jobs, adequate housing and other basic necessities. Rapid growth of developed nations is due to the fast growth of over population. Lewis Model of structural change argued that migration was necessary for the growth of an urban industrial sector which would lead to economic growth. Migration is due to many reasons, unemployment, underemployment, demand for labour not risen in line with rapid growing labour supply, inability to create jobs sufficiently quickly, lower standard of living, employment in informal sector, pressure of housing stock, overcrowding, and negative externality. This study will analyze and discuss international migration that has been seen with loss of skilled workers, professionals are often tempted by the opportunity of higher living standards elsewhere, many countries are now seeking deliberately to attract immigrants in order to fill skill gaps and boost the production possibilities of their own economies, work remittances are increasingly valuable source of income to developing countries. Specifically, the main objective of this study is to analyze the magnitude of expatriates pull factors into the GCC Countries and their contribution towards effectiveness and efficiency in the growth of these countries.
\end{abstract}

Keywords: Expatriates, Pull Factors, Push Factors, GCC, Rural-Urban Migration

\section{Introduction}

Most of the GCC nations there were oil boom in 1970s, and 1980s which encouraged labour migration to these countries. But in 1990s, however these countries witnessed rapid deceleration in the net inflows of labour. Migration has become a global issue in this world. People living outside their own country have doubled since 1975 . If you compare the countries having more than 500,00 migrants it has increased from $30 \%$ to $62 \%$. Migration is mainly due to speedy industrialization, political and cultural developments and radical environmental changes. Many theories been developed with regard to the development of international migration. Models In the micro level decision models, the main reason of migrants in developed nations is due to low wage. [1] Abrajano, Marisa, \& Zoltan L. Hajnal (2015). The five largest immigrant groups of GCC are from India, Pakistan, Bangladesh, Iran, and the Philippines. [3] (Baldwin, 2012)

Migration into a country has two aspects push and pull factors. In respect of this the migrants should not only see the lack of benefits in the home country but also see the abundant benefits given by the receiving country. Recently even the network factors also have started influencing people to move. The potential role in international migration is offsetting population decline and population ageing. Migration has become a global phenomenon, with growing countries involved sending and receiving countries. Virtually all those countries experiencing low fertility, the impact of international countries may have on the demographic challenges of ageing. Increase in the demand for demographic considerations will increase because of the rigidities in the labour market and social security [12] (Organization for Economic Cooperation and Development, 2011)

Individuals are rational in decision making; they will make a choice only if it benefits them. They always look for the incentives to make a move. Migration might still be made on economic sense. Model helps us to understand continued migration within a standard economic framework but it has 
been argued that individuals in developing countries are likely to reluctant to take risks.

The most recent era of mass voluntary migration was between $1850-1994,10 \%$ of the world's population was migrating during this period, whereas now its 3\% (World Bank report). Globalization caused people to move by gradually lowering the barriers to their movement across border. In 2005, the GCC nations accommodated over around 12 million international migrants mainly working under service sector and construction industries. [1] Abrajano, Marisa, \& Zoltan L. Hajnal (2015)
Massive inflow of migrants could be to increase the population of a country, increases productivity and it is an asset to the receiving nation. [7] Clarke, H., Y. K. Ng. (2003) argues to maintain the dependency ratio it is better to maintain the retirement age rather than resorting to migration from abroad. Migration to GCC regions is mainly due to highly hour wage, labour demand, transnational religion, medical care, education, family links, personal fondness, free flow of information, improved global communication, improve economic conditions.

\section{Theoretical Framework}

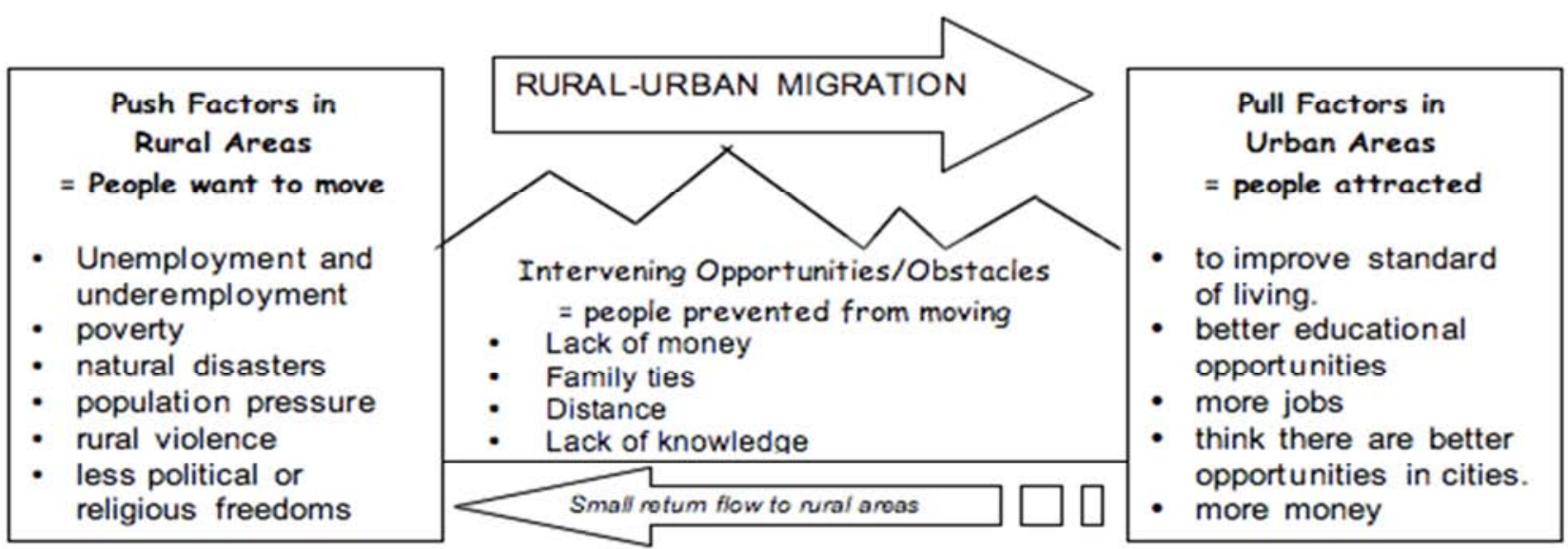

Source: http// tbc.school.nz

Figure 1. Migration Model.

The above model shows how people migrate using a step wise migration. In this model people are likely to move form a small rural are to a small urban area; people who live in small cities move to bigger cities'. As a result of urbanization process the percentage of people moving is more. The poor standard of living may have forced migrants to go back to rural areas as well. (Return to countryside). International migration is also possible with rapid growing economies. Countries have attracted workers from different parts of the world. Another major migration has been that of migration refugees. [9] Modarres, Ali, (2010)

\section{Lee's Push-Pull Theory}

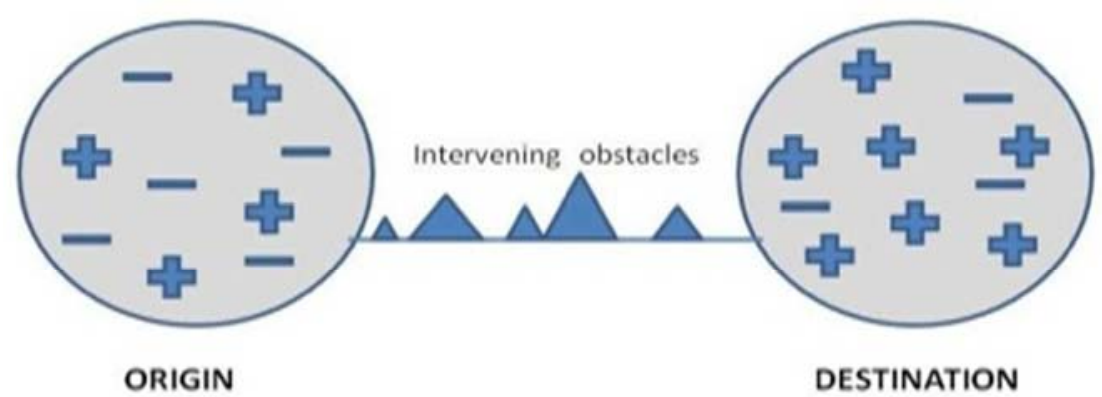

Figure 2. Less Push and Pull Theory.

This model shows how push and pull factors affect the migration of people. The movement is between the two countries but there are usual interruptions to these spatial movements. The interruptions are represented in between the 
two nations for example preventive immigration laws can be an obstacle to forthcoming migrants. It also indicates both the sending nation and receiving nation have push and pull factors and migrants should take into consideration the positives of staying and negatives of moving. The logic of this model is that if the factors at the receiving nation outweigh the factors at origin then the migration is likely to occur.

\section{Conceptual Framework}

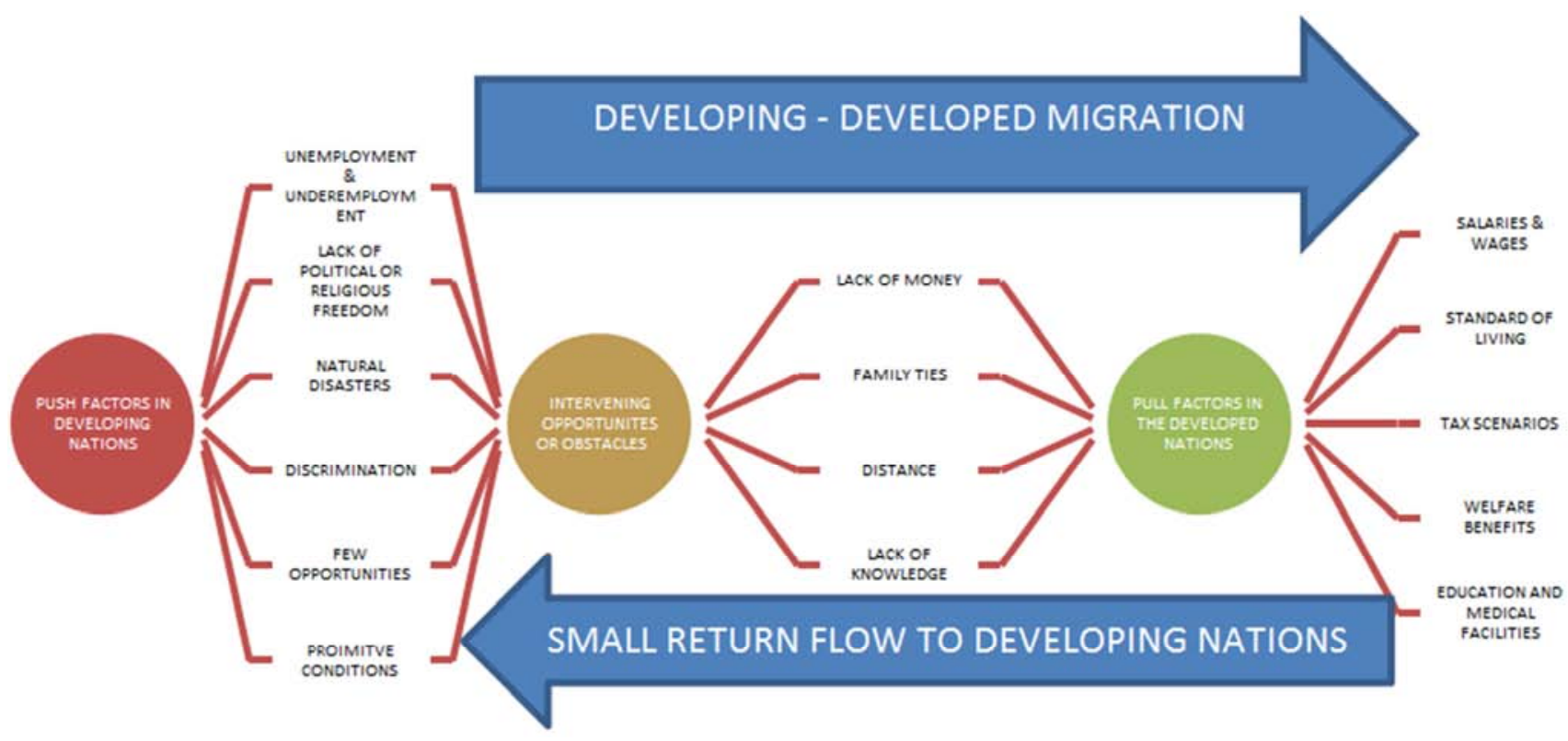

Figure 3. Process of Migration from Developing Nations to Developed Nations.

The following dimensions were conceptualized as a framework of this study. These push and pull factors of migration are analyzed in both the developed economies and developing economies. Some people have different views on why people migrate; there is absolutely no single model of immigration. Sociologists, economists, politicians, and policy makers have different set of views about migration.

\section{Research Design}

This research study primarily utilizes the descriptive method of research. The design of the research has mainly to do with the knowledge of the subject under investigation. The main determination of doing descriptive research is to gather data for various reasons and from many different methods. Through this type of research we get an idea of the frequencies, averages, and other statistical calculations. This type of research is used so that the researcher wants to gain a better understanding of a topic.

We get a description of data as a result of using the descriptive research, in the form of words, diagrams, pictures, charts, or tables. In this type, it provides explanations of the variables in order to answer the question no matter what method is chosen to collect the data. In this study, descriptive design has been used in order to describe the variables articulated in the statement of problem which are Salaries and wages, Tax scenarios, Standard of living, Welfare benefits, Education and medical facilities

Table 1. Status of the magnitude of expatriates pull factors in the GCC Countries.

\begin{tabular}{|c|c|c|c|c|c|c|c|}
\hline \multirow{2}{*}{\multicolumn{2}{|c|}{$\begin{array}{l}\text { E Status of the magnitude of expatriates pull factors in the } \\
\text { GCC Countries: Salaries and Wages }\end{array}$}} & \multicolumn{2}{|c|}{ Professional level } & \multicolumn{2}{|c|}{ Skilled workers level } & \multicolumn{2}{|c|}{ Composite } \\
\hline & & \multirow{2}{*}{$\begin{array}{l}\text { Mean } \\
4.1\end{array}$} & \multirow{2}{*}{$\begin{array}{l}\text { Interpretation } \\
\text { Agree }\end{array}$} & \multirow{2}{*}{$\begin{array}{l}\text { Mean } \\
4.1\end{array}$} & \multirow{2}{*}{$\begin{array}{l}\text { Interpretation } \\
\text { Agree }\end{array}$} & \multirow{2}{*}{$\begin{array}{l}\begin{array}{l}\text { Final } \\
\text { Mean }\end{array} \\
4.1\end{array}$} & \multirow{2}{*}{$\begin{array}{l}\text { Final } \\
\text { interpretation } \\
\text { Agree }\end{array}$} \\
\hline 1 & $\begin{array}{l}\text { Allows the migrants from different nations to be a good } \\
\text { human capital resulting in societal changes. }\end{array}$ & & & & & & \\
\hline 2 & $\begin{array}{l}\text { Results in increased level of productivity which lead to } \\
\text { effectiveness and efficiency }\end{array}$ & 3.9 & Agree & 3.7 & Agree & 3.8 & Agree \\
\hline 3 & $\begin{array}{l}\text { Promotes justice in recruiting and adequate working } \\
\text { conditions }\end{array}$ & 3.5 & Agree & 3.7 & Agree & 3.8 & Agree \\
\hline 4 & $\begin{array}{l}\text { Leads to positive gain because the skilled manpower will be } \\
\text { subsidized and there will be faster growth in the country. }\end{array}$ & 4.1 & Strongly Agree & 3.9 & Agree & 4.0 & Agree \\
\hline \multirow[t]{2}{*}{5} & $\begin{array}{l}\text { Offers opportunities for industry expansion and formation } \\
\text { of new industries. }\end{array}$ & 4.3 & Strongly Agree & 3.6 & Agree & 4.0 & Agree \\
\hline & AVERAGE & 4.0 & & 3.81 & & 3.9 & \\
\hline
\end{tabular}


The above table reveals the overall perceptions of the professionals. The professional were teachers, chartered accountants, engineers, doctors and IT experts. The professionals agreed that the pull factors for migration in the Gulf Regions is Salaries and Wages as indicated by average composite mean of 3.88

Among the perception from the above table, the lowest mean average is 3.5 seen from the professionals for Status of the magnitude of expatriates pull factors in the Gulf Regions: Salaries and Wages. Professionals and skilled migrants had a difference of perceptions is this criteria-(Promotes justice in recruiting and adequate working conditions). [11] Neda Samiei, Mohammad Reza Jalilvand (2014)

Table 2. Status of the magnitude of expatriates pull factors in the GCC Countries.

\begin{tabular}{|c|c|c|c|c|c|c|c|}
\hline \multirow{2}{*}{\multicolumn{2}{|c|}{$\begin{array}{l}\text { Status of the magnitude of expatriates pull factors in the GCC Countries: } \\
\text { Tax scenarios }\end{array}$}} & \multicolumn{2}{|c|}{ Professional level } & \multicolumn{2}{|c|}{ Skilled workers level } & \multicolumn{2}{|c|}{ Composite } \\
\hline & & \multirow{2}{*}{$\begin{array}{l}\text { Mean } \\
4.2\end{array}$} & \multirow{2}{*}{$\begin{array}{l}\text { Interpretation } \\
\text { agreed }\end{array}$} & \multirow{2}{*}{$\begin{array}{l}\text { Mean } \\
4.1\end{array}$} & \multirow{2}{*}{$\begin{array}{l}\text { Interpretation } \\
\text { Agreed }\end{array}$} & \multirow{2}{*}{$\begin{array}{l}\text { Final } \\
\text { Mean } \\
4.2\end{array}$} & \multirow{2}{*}{$\begin{array}{l}\text { Final } \\
\text { interpretation } \\
\text { agreed }\end{array}$} \\
\hline 1 & Promotes and ensures proper saving facilities for retirement. & & & & & & \\
\hline 2 & Encourages people to work harder and increase high productivity. & 4.2 & Agreed & 3.9 & Agreed & 4.0 & agreed \\
\hline 3 & $\begin{array}{l}\text { Encourages investment due to duty free imports so that industries can } \\
\text { produce more products and offering more services. }\end{array}$ & 4.1 & agreed & 4.1 & Agreed & 4.1 & Agreed \\
\hline \multirow[t]{2}{*}{5} & Attracts and creates economic benefits, bonus and other pension schemes & 3.7 & agreed & 3.7 & Agreed & 3.7 & agreed \\
\hline & Average & 4.0 & & 3.9 & & 4.0 & \\
\hline
\end{tabular}

Perception from Table shows how the professionals and skilled migrants feel on the Status of the magnitude of expatriates pull factors in the GCC Countries: Tax scenarios. It shows that the professional group has agreed that the tax scenario is one of the reasons for the expatriates to migrate to KOB. The highest mean under the professional migrants is seen under 4 places, first. It Promotes and ensures proper saving facilities for retirement. Second it encourages people to work harder and increase high productivity. Third it encourages investment due to duty free imports so that industries can produce more products and offering more services. Fourth it promotes total patterns of consumption and cost of living. All the four points scored an average mean above 4.0 In contrast, the perceptions under the skilled migrant's shows that the mean rate is above 4.0 in just 2 places. First, they also agree that it promotes and ensures proper saving facilities for retirement. Second, it encourages investment due to duty free imports so that industries can produce more products and offering more services. This reflects that the reason for migration is to some extent the tax scenario. The reason of such perception is indeed supported by the 2010 financial development report published by world economic forum that said Bahrain has the fourth most favorable tax regime in the world out of 55 leading economies surveyed. The economic vision of GCC of course, tax policy is one of the country's attractive features. This perception is similar to OBG talks, Ali Jawad Habib, Head of Business Development BDO had said since the country has no personal tax not corporate tax it leads to low cost of living. The country's fiscal policies help both the individual and the corporations to a large extent. [12] The Report Bahrain 2011

Table 3. Status of the magnitude of expatriates pull factors in the GCC Countries.

\begin{tabular}{|c|c|c|c|c|c|c|c|}
\hline \multirow{2}{*}{\multicolumn{2}{|c|}{$\begin{array}{l}\text { E Status of the magnitude of expatriates pull factors in the } \\
\text { GCC Countries: Standard of living }\end{array}$}} & \multicolumn{2}{|c|}{ Professional level } & \multicolumn{2}{|c|}{ Skilled workers level } & \multicolumn{2}{|c|}{ Composite } \\
\hline & & \multirow{2}{*}{$\begin{array}{l}\text { Mean } \\
4.4\end{array}$} & \multirow{2}{*}{$\begin{array}{l}\text { Interpretation } \\
\text { agreed }\end{array}$} & \multirow{2}{*}{$\begin{array}{l}\text { Mean } \\
4.3\end{array}$} & \multirow{2}{*}{$\begin{array}{l}\text { Interpretation } \\
\text { Agreed }\end{array}$} & \multirow{2}{*}{$\begin{array}{l}\text { Final } \\
\text { Mean }\end{array}$} & \multirow{2}{*}{$\begin{array}{l}\text { Final } \\
\text { interpretation }\end{array}$} \\
\hline 1 & $\begin{array}{l}\text { Allows people to enjoy higher level of consumption of goods } \\
\text { and services. }\end{array}$ & & & & & & \\
\hline 2 & $\begin{array}{l}\text { Provides opportunities to acquire economic steadiness and } \\
\text { ensures a flexible income }\end{array}$ & 3.9 & Agreed & 3.8 & Agreed & 3.9 & Agreed \\
\hline 3 & $\begin{array}{l}\text { Enables fullness of life through development of business to } \\
\text { produce necessary goods and services. }\end{array}$ & 4.1 & Agreed & 3.7 & Agreed & 3.9 & Agreed \\
\hline 4 & $\begin{array}{l}\text { Ensures good social security, lack of gender bias, freedom of } \\
\text { choice, leisure and liberties. }\end{array}$ & 4.0 & Agreed & 3.6 & Agreed & 3.8 & Agreed \\
\hline \multirow[t]{2}{*}{5} & $\begin{array}{l}\text { Encourages accomplishment of good health, good } \\
\text { environment and good educated, skilled and healthy workers. }\end{array}$ & 3.9 & Agreed & 3.9 & Agreed & 3.9 & agreed \\
\hline & Average & 4.1 & & 3.9 & & 4.0 & \\
\hline
\end{tabular}

The perceptions of professional migrants and skilled migrants are almost similar to each other. The reason of such perception is that a community which has a high standard of living enjoys a better quality of life, provide ample opportunities for young generation, provide quality goods and services, consistent education and health facilities and the population of such country earn higher wages and allow money to be spent on quality housing and nutrition. This study is aligned with seminal work based on a model of interregional migration is characterized by a certain degree of selectivity. The Todaro model suggests that younger migrants increase the time period for expected income 
Table 4. Status of the magnitude of expatriates pull factors in the GCC Countries.

\begin{tabular}{llllllll}
\hline E Status of the magnitude of expatriates pull factors in the & \multicolumn{2}{l}{ Professional level } & \multicolumn{2}{l}{ Skilled workers level } & Composite \\
\cline { 2 - 7 } GCC Countries: Welfare benefits & Mean & Interpretation & Mean & Interpretation & Final Mean & Final interpretation \\
\hline 1 & $\begin{array}{l}\text { Ensures change and helps people to take advantage of most } \\
\text { which GCC offers. }\end{array}$ & 4.0 & Agreed & 3.9 & Agreed & 4.0 & Agreed \\
2 & $\begin{array}{l}\text { Provides good lifestyle and good care of all infrastructures. } \\
\text { Encourages people to get better job and get a career in }\end{array}$ & 4.9 & Agreed & 3.8 & Agreed & 3.9 & Agreed \\
3 & $\begin{array}{l}\text { Agreed } \\
\text { future. }\end{array}$ & 3.7 & Agreed & 3.9 & Agreed \\
$\begin{array}{l}\text { Assures effective social protection by treating people with } \\
\text { dignity and respect }\end{array}$ & 3.9 & agreed & 3.7 & Agreed & 3.8 & agreed \\
$\begin{array}{l}\text { Encouraged to follow and achieve a variety of challenging } \\
\text { objectives. }\end{array}$ & 3.9 & agreed & 3.9 & Agreed & 3.9 & Agreed \\
average & 3.8 & & 3.9 & & 3.9 & \\
\hline
\end{tabular}

The above table presents the perception of professional migrants and skilled migrants with regard to the Status of the magnitude of expatriates pull factors in the GCC Countries: welfare benefits. In this criterion the skilled migrants have mean average below 4.0 in almost all 5 indicators. The highest average mean under professional migrants is 4.0 in 2 indicators, first it ensures change and helps people to take advantage of most which KOB offers and secondly it encourages people to get better job and get a career in future which reflects that the professional migrants perception with regard to the welfare benefits is better for the only reason that they feel the benefits is payable to expatriate at the completion of their employment contract in Bahrain, Oman and UAE. According to the article around $29 \%$ of the total $\$ 535 \mathrm{~m}$ in gross premiums earned by the insurance industry went towards life segment. [6] Biasco, G. J. (2009).

Table 5. Status of the magnitude of expatriates pull factors in the GCC.

\begin{tabular}{|c|c|c|c|c|c|c|c|}
\hline \multirow{2}{*}{\multicolumn{2}{|c|}{$\begin{array}{l}\text { E Status of the magnitude of expatriates pull factors in the } \\
\text { GCC Countries: Education and Medical benefits }\end{array}$}} & \multicolumn{2}{|c|}{ Professional level } & \multicolumn{2}{|c|}{ Skilled workers level } & \multicolumn{2}{|c|}{ Composite } \\
\hline & & \multirow{2}{*}{$\begin{array}{l}\text { Mean } \\
4.2\end{array}$} & \multirow{2}{*}{$\begin{array}{l}\text { Interpretation } \\
\text { Agreed }\end{array}$} & \multirow{2}{*}{$\begin{array}{l}\text { Mean } \\
4.0\end{array}$} & \multirow{2}{*}{$\begin{array}{l}\text { Interpretation } \\
\text { Agreed }\end{array}$} & \multirow{2}{*}{$\begin{array}{l}\text { Final } \\
\text { Mean }\end{array}$} & \multirow{2}{*}{$\begin{array}{l}\begin{array}{l}\text { Final } \\
\text { interpretation }\end{array} \\
\text { Agreed }\end{array}$} \\
\hline 1 & $\begin{array}{l}\text { Ensures longer lifespans indicating people have good access } \\
\text { to vaccines, checkups, and medical treatments. }\end{array}$ & & & & & & \\
\hline 2 & $\begin{array}{l}\text { Allows people to demand high wages and permit money to be } \\
\text { spent on quality food, housing and business expansion }\end{array}$ & 4.2 & Agreed & 3.7 & Agreed & 4.0 & Agreed \\
\hline 3 & $\begin{array}{l}\text { Provides with productive employment opportunities and earn } \\
\text { good income levels. }\end{array}$ & 3.8 & Agreed & 3.8 & Agreed & 3.8 & Agreed \\
\hline 4 & $\begin{array}{l}\text { Allows and ensure good education benefits to your children, } \\
\text { providing different levels of curriculum of your choice. }\end{array}$ & 3.9 & Agreed & 3.7 & Agreed & 3.8 & Agreed \\
\hline \multirow[t]{2}{*}{5} & $\begin{array}{l}\text { Maintains good environmental conditions and protects from } \\
\text { exposing to pollution or toxins and diseases }\end{array}$ & 4.2 & Agreed & 3.9 & Agreed & 4.1 & Agreed \\
\hline & average & 4.1 & & 3.8 & & 4.0 & \\
\hline
\end{tabular}

This study shows that this is one of the reasons for migration. From the above table you will see the under the professional migrants the average mean in 3 indicators are above 4.0. First it ensures longer lifespans indicating people have good access to vaccines, checkups, and medical treatments, second allows people to demand high wages and permit money to be spent on quality food, housing and business expansion and thirdly Maintains good environmental conditions and protects from exposing to pollution or toxins and diseases. This is supported by the OBG talk to Mohammed Khalil Alsayed CEO Ithmaar Development Company. He said Bahrain economy will benefit from significant advancements in medical and the most Important in the medium term is the development of human capital. [10] Mohammed Dito, October 2010

\section{Conclusion}

Generally migration seeks the surplus benefits (pull factor). Recent migrants are taken due to employment based preferences. The demand for labour is very high. Higher standard of living and higher wages attracts the potential migrants easily. It is noticed there is greater safety net of welfare benefits. Many jobs are created in the country but the local workers refuse to fill the gaps. Business and construction that always face shortage of labour benefit from being able to get cheap labour. The expansion of telecommunication and technology shows the country is need of IT experts and skilled workers. The net effect of migration into KOB is always positive. Economists who support the notion of positive gains claim that migration has little impact on wages or job availability for domestic workers.

\section{References}

[1] Abrajano, Marisa, \& Zoltan L. Hajnal (2015). White Backlash: Immigration, Race, and American Politics. Princeton, NJ: Princeton University Press.

[2] Arfan G. H., (2010) "Gender and Migration in Arab States: The Case of Domestic Workers" 
[3] Baldwin-Edwards, Martin. 2012. Labour immigration and labor markets in the GCC countries: national patterns and trends. LSE Kuwait Programme on Development, Governance and Globalisation in the Gulf States. WP 15.

[4] Boeri, T., Hanson, G. and McCormick, B. (Eds.). (2002). Immigration Policy and the Welfare System. Oxford: Oxford University Press.

[5] Borjas, G. J. (2011). The Economic Benefits from Immigration. Journal of Economic Perspectives, 9, 3-22.

[6] Biasco, G. J. (2009). Immigration and Welfare of Labor Supply. Journal of Labor Economics 2009, 7-14.

[7] Clarke, H., Y. K. Ng. (2003). Immigration and Economic Welfare: Resource and Environmental Aspects. Economic Record, 69 (206), 259-273.
[8] Fatima Rasool, christoff J Botha, (2011) The nature, extent and effect of skills migration in south Africa. SA Journal of Human Resource Management; Vol 9, No 1.

[9] Modarres, Ali, (2010), Migration and the Persian Gulf: Demography, Identity and the Road to Equitable Policies: An Analysis of International Migration Theories.

[10] Mohammed Dito, October 23-25, 2010 migration policies and challenges in the kingdom of Bahrain.

[11] Neda Samiei, Mohammad Reza Jalilvand (2014): The Effect of Migration on Government Size Case study: Some Selected Middle-East Countries.

[12] Organization for Economic Cooperation and Development, Development Cooperation Report of 2011, OECD.org. The Report Bahrain 2011: Oxford Business group, www. Oxford business group.com/International Migration Outlook. 